\title{
Using the combined bioelectrochemical and sulfur autotrophic denitrification system for groundwater denitrification
}

\author{
Dongjin Wan ${ }^{\mathrm{a}, \mathrm{b}}$, Huijuan Liu ${ }^{\mathrm{a}}$, Jiuhui Qu ${ }^{\mathrm{a}, *}$, Pengju Lei ${ }^{\mathrm{a}}$, Shuhu Xiao ${ }^{\mathrm{a}, \mathrm{b}}$, Yining Hou ${ }^{\mathrm{a}, \mathrm{b}}$ \\ a State Key Laboratory of Environmental Aquatic Chemistry, Research Center for Eco-Environmental Sciences, Chinese Academy of Sciences, Beijing 100085, China \\ ${ }^{\mathrm{b}}$ Graduate University of Chinese Academy of Sciences, Beijing 100039, China
}

\section{A R T I C L E I N F O}

\section{Article history:}

Received 27 March 2008

Received in revised form 27 May 2008

Accepted 28 May 2008

Available online 10 July 2008

\section{Keywords:}

Bioelectrochemical

Hydrogen

Sulfur

Autotrophic denitrification

Groundwater

\begin{abstract}
A B S T R A C T
A combined bioelectrochemical and sulfur autotrophic denitrification system (CBSAD) was evaluated to treat a groundwater with nitrate contamination (20.9-22.0 $\left.\mathrm{mg} \mathrm{NO}_{3}^{-}-\mathrm{N} / \mathrm{L}\right)$. The reactor was operated continuously for several months with groundwater to maximize treatment efficiency under different hydraulic retention times (HRT) and electric currents. The denitrification rate of sulfur autotrophic part followed a half-order kinetics model. Moreover, the removal efficiency of bioelectrochemical part depended on the electric current. The reactor could be operated efficiently at the HRT ranged from 4.2 to $2.1 \mathrm{~h}$ (corresponding nitrogen volume-loading rates varied from 0.12 to $0.24 \mathrm{~kg} \mathrm{~N} / \mathrm{m}^{3} \mathrm{~d}$; and optimum current ranged from 30 to $1000 \mathrm{~mA}$ ), and the $\mathrm{NO}_{3}^{-}-\mathrm{N}$ removal rate ranged from $95 \%$ to $100 \%$ without $\mathrm{NO}_{3}^{-}-\mathrm{N}$ accumulation. The $\mathrm{pH}$ of effluent was satisfactorily adjusted by bioelectrochemical part, and the sulfate concentration of effluent was lower than $250 \mathrm{mg} / \mathrm{L}$, meeting the drinking water standard of China EPA.
\end{abstract}

(c) 2008 Elsevier Ltd. All rights reserved.

\section{Introduction}

Nitrate as a kind of common contaminates in groundwater aquifers has steadily been increasing in recent years mainly due to the extensive use of nitrogen fertilizers and improper treatment of waste water from the industrial sites. It was discovered that for ground water from $10 \%$ to $25 \%$ of the water-supply wells in large region of the US exceeded the maximum contaminant level for nitrate (10 $\mathrm{mg} \mathrm{NO}_{3}^{-}-\mathrm{N} / \mathrm{L}$ ) (Nolan et al., 1997). In China, the pollution of nitrate in ground water was even more severe, nitrate concentration of groundwater in some rural area even exceeded $130 \mathrm{mg}$ $\mathrm{NO}_{3}^{-}-\mathrm{N} / \mathrm{L}$. Ground water is a universal, and in some cases exclusive, drinking-water source used for both humans and livestock in rural and suburban areas. Because of its health risks, removing nitrate from groundwater has gained great attention in recent years (Kleinjans et al., 1991). The methods that can remove nitrate from groundwater mainly include ion exchange (IE) (Chen et al, 2002; Samatya et al, 2006), reverse osmosis (RO), catalytical (Prüsse et al., 2000) and biological process. However, IE and RO processes can not transfer nitrate into harmless compounds but only concentrate nitrate from water to brine and need afterwards treatment; catalytical process may generate more toxic byproduct (such as $\mathrm{NO}_{2}^{-}$and $\mathrm{NH}_{4}^{+}$) and it is still in the experimental test stage (Prüsse

\footnotetext{
* Corresponding author. Tel.: +8610 62849151; fax: +861062923558.

E-mail addresses: dongjin1096@yahoo.com.cn (D. Wan), hjliu@rcees.ac.cn (H. Liu), jhqu@rcees.ac.cn (J. Qu), leipengju@yahoo.com.cn (P. Lei), xiaoshuhu@126. com (S. Xiao), yininghou1103@126.com (Y. Hou).
}

et al., 2000). Only biological denitrification is the most favorable way to remove nitrate and it is successfully used for nitrate contaminated groundwater treatment.

Heterotrophic biological denitrification of drinking water has been widely applied because of its high efficiency and low cost, but residual carbon sources (such as methanol, ethanol or acetic acid, etc.) may cause many problems in drinking water treatment. Since groundwater always has a very low concentration of biodegradable organic materials, autotrophic denitrification which utilizes $\mathrm{CO}_{2}$ as their carbon source from water requires addition of an electron donor substrate. Elemental sulfur (Batchelor and Lawerence, 1978; Claus and Kutzner, 1985; Wang, 1998; Koenig and Liu, 2001; Liu and Koenig, 2002; Kimura et al., 2002; Moon et al., 2004; Zeng and Zhang, 2005; Sierra-Alvarez et al., 2007) and $\mathrm{H}_{2}$ (Mansell and Schroeder, 2002; Rezania et al., 2007) as electron donor for autotrophic denitrification systems has been studied extensively.

The sulfur-limestone autotrophic denitrification (SLAD) process for treatment of nitrate contaminated water has been studied and applied for decades in Europe and USA. Element sulfur is used as electron donor and limestone is used to adjust the $\mathrm{pH}$, but the increase of sulfate concentration and hardness limits its application. Hydrogen gas is an ideal electron donor for biological autotrophic denitrification that it is completely harmless to drinking water, and no further steps are needed to remove either excess substrate or its derivatives. However, it has a poor solubility in water (1.6 mg/L at $20^{\circ} \mathrm{C}$ ) and dangerous to control. To overcome the above mentioned problems, development of a new appropriate 
treatment method is required. Biofilm-electrode reactor as an electrochemical and biological reactor was firstly developed by Sakakibara et al. in 1993 (Sakakibara and Kuroda, 1993). In this system, autotrophic denitrifying microorganisms was immobilized on the surface of the cathode, hydrogen gas as an electron donor was produced of by electrolysis of water. Considerable efforts had been taken to improve designs for the efficient and economical removal of nitrate from water by bioelectrochemical denitrification recently (Sakakibara et al., 1994; Feleke et al., 1998; Sakakibara and Nakayama, 2001; Szekeres et al., 2001; Feleke and Sakaibara, 2002; Prosnansky et al, 2002).

Combined bioelectrochemical and sulfur autotrophic denitrification system (CBSAD) for drinking water denitrification was firstly proposed in our previous study (Wang and Qu, 2003). In such process, sulfur autotrophic and hydrogen autotrophic were integrated for the following reasons: the $\mathrm{H}^{+}$generated in sulfur denitrification could be consumed by the bioelectrochemical hydrogen denitrification to achieve neutralization, thus the limestone added in SLAD system could be cancelled and the hardness increase could be avoided in this process; the sulfate concentration of effluent could be controlled by the nitrogen load of sulfur autotrophic denitrification part, and would be lower than SLAD process. In this study, the CBSAD system amplified with $33.47 \mathrm{~L}$ effective volume was established and evaluated for groundwater denitrification. The system was operated at various water effluent flux (or nitrogen volume-loading rates) and current intensities for 105 days. Its optimum operation conditions were also determined in this study.

\section{Methods}

\subsection{Experimental apparatus}

The experimental apparatus used in this study is shown schematically in Fig. 1. The reactor consisted of two parts: sulfur autotrophic denitrification part (mentioned as S-part) and bioelectrochemical

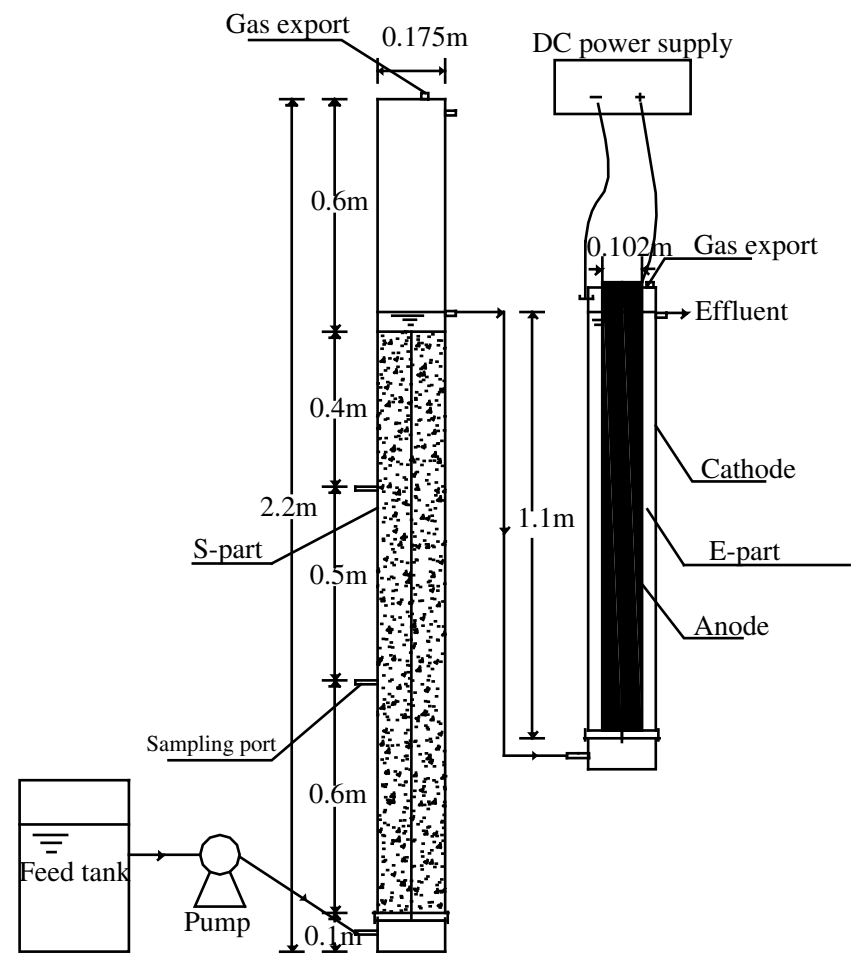

Fig. 1. Schematic drawing of continuous-flow reactor. hydrogen autotrophic denitrification part (mentioned as E-part). The groundwater from feed tank was pumped to the S-part first and then to the E-part, the inflow flux was controlled by influent pump, ranged from $7.97 \mathrm{~L} / \mathrm{h}$ to $15.93 \mathrm{~L} / \mathrm{h}$. The total effective liquid volume of the reactor was $33.47 \mathrm{~L}$.

The S-part was a stainless steel cylindrical with $17.5 \mathrm{~cm}$ diameter and $2.2 \mathrm{~m}$ length. $1.5 \mathrm{~m}$ of sulfur part was packed with sulfur and anthracite granules (1:1 v/v, 3-4 mm diameter YanShanpc Co., Ltd., Beijing, China). The porosity of the medium column is $40 \%$, thus the effective pore water volume of sulfur part was $14.43 \mathrm{~L}$. Three sample ports were fixed at different height of S-part for kinetic study. E-part was made of stainless steel column with $17.5 \mathrm{~cm}$ diameter and $1.1 \mathrm{~m}$ length, and its effective liquid volume was $19.04 \mathrm{~L}$. The anode was carbon rod of $10.2 \mathrm{~cm}$ diameter, and the cathode was the cylindrical stainless steel wall with $6594 \mathrm{~cm}^{2}$ surface area. The distance between the electrodes was $3.65 \mathrm{~cm}$. The reactor was operated under room temperature $\left(21 \pm 2{ }^{\circ} \mathrm{C}\right)$. The water flow was upward and isolated from the air to preserve an anaerobic environment within the column. Direct current was supplied by Silicon Rectifier (Model DH1718E-4, Beijing Dahua Electronic Instruments Group, Beijing, China).

The influent water in this study was a groundwater with nitrate contamination in Fengtai district, Beijing. The details of the influent water and the experimental conditions in this study were: well depth $37 \mathrm{~m}, \mathrm{pH} 7.10-7.34, \mathrm{NO}_{3}^{-}-\mathrm{N} 20.9-22.0 \mathrm{mg} / \mathrm{L}, \mathrm{NO}_{2}^{-}-\mathrm{N}$ Not detected, DO $3.5-4.9 \mathrm{mg} / \mathrm{L}$, Alkalinity $\left(\mathrm{CaCO}_{3}\right) 420.11 \mathrm{mg} / \mathrm{L}$, Conductivity $1210 \mu \mathrm{S}$, IC $93 \mathrm{mg} / \mathrm{L}, \quad$ TOC $2 \mathrm{mg} / \mathrm{L}, \quad$ COD $8 \mathrm{mg} / \mathrm{L}, \mathrm{SO}_{4}^{2-}$ $101.86 \mathrm{mg} / \mathrm{L}$ and $\mathrm{Cl}^{-} 105.61 \mathrm{mg} / \mathrm{L}$.

\subsection{Bacterial inoculation and acclimation}

The bioreactor was inoculated and acclimated according to the method described in detail in our previous publication (Wang and $\mathrm{Qu}, 2003)$. Under continuous-flow, with the applied electric current of $80 \mathrm{~mA}$, biofilm was formed on the cathode and sulfur granule surface in about 25 days.

\subsection{Experimental design}

During the whole operating time of 105 days, the hydraulic retention time (HRT) was maintained at 4.2, 3.6, 3.0, 2.4 and $2.1 \mathrm{~h}$ for 21 days each to investigate the effect of HRT. Correspondingly, the nitrogen volume-loading rate was maintained at 0.12 , $0.14,0.17,0.20,0.24 \mathrm{~kg} \mathrm{~N} / \mathrm{m}^{3} \mathrm{~d}$. Direct current were applied to the reactor sequentially, $30-400 \mathrm{~mA}$ for HRT of $4.2,3.6,3.0 \mathrm{~h}$; and $180-1200 \mathrm{~mA}$ for HRT of $2.4 \mathrm{~h}$ and $2.1 \mathrm{~h}$.

Since the groundwater contained a trace amount of phosphate $(6 \mathrm{mg} / \mathrm{L})$, no phosphates added to the influent as nutrition during the whole operating time. As DO of this groundwater (3.5$4.9 \mathrm{mg} / \mathrm{L}$ ) was much lower than surface water, no method was used to remove DO and the water flow was upward and isolated from the air to keep an anaerobic environment within the column.

During electrical process, it was necessary to prevent $\mathrm{O}_{2}$ generated on anode. For carbon rod anode reaction, $\mathrm{CO}_{2}$ is formed prior to $\mathrm{O}_{2}$ for their electrode potential at low applied voltage (Wang and $\mathrm{Qu}, 2003)$, so it was essential to operate the reactor under 30-1200 mA (corresponding voltage was $0.5-5.5 \mathrm{~V}$ ) to test its electrical chemical changes and find maximum applied current. The results showed that ORP decreased slowly from $-20 \mathrm{mV}$ to $-50 \mathrm{mV}$ when applied current increased from 30 to $1000 \mathrm{~mA}$; and increased sharply to $+20 \mathrm{mV}$ under $1200 \mathrm{~mA}$ applied current. Therefore, the maximum applied current was fixed at $1000 \mathrm{~mA}$ (corresponding voltage was $5.0 \mathrm{~V}$ ) in order to prevent $\mathrm{O}_{2}$ generated at anode.

Under different HRT and different currents, the system run and stabilized 3.5 days and steady-state condition was achieved when 
variation of sample data of three sequential retention times was less than $5 \%$. Optimum operation conditions was determined at different HRT with minimum applied current to achieve more than 95\% nitrate removal efficiency and without accumulation of nitrate.

\subsection{Analytical methods}

The $\mathrm{NO}_{3}^{-}-\mathrm{N}, \mathrm{NO}_{2}^{-}-\mathrm{N}, \mathrm{SO}_{4}^{2-}, \mathrm{S}_{2} \mathrm{O}_{3}^{2-}, \mathrm{pH}, \mathrm{TOC}$ and turbidity of the influent, effluent from S-part and E-part was measured at each steady-state condition. Samples were passed through $0.45 \mu \mathrm{m}$ membrane for $\mathrm{NO}_{3}^{-}-\mathrm{N}, \mathrm{NO}_{2}^{-}-\mathrm{N}, \mathrm{SO}_{4}^{2-}$ and $\mathrm{S}_{2} \mathrm{O}_{3}^{2-}$ measurement. The concentrations of $\mathrm{NO}_{3}^{-}-\mathrm{N}, \mathrm{NO}_{2}^{-}-\mathrm{N}, \mathrm{SO}_{4}^{2-}$ and $\mathrm{S}_{2} \mathrm{O}_{3}^{2-}$ were determined by ion chromatograph (Metrohm 861, Switzerland). TOC was measured by a TOC analyzer (Jena multi N/C 3000, Germany). COD was measured by a COD analyzer (HACH DRB200 and DR/2800, USA). VSS was determined according to Standard Methods (APHA et al., 1992). The DO, pH, ORP and Conductivity were measured by multi parameters portable instruments (HACH Sension, USA). Turbidity was determined with a turbidity meter (HACH $2100 \mathrm{~N}$, USA).

\section{Results and discussion}

\subsection{Principle of the CBSAD system}

In the CBSAD process, nitrate is firstly reduced to nitrogen gas by the biofilm on sulfur granule surface in $\mathrm{S}$-part, and $\mathrm{H}^{+}$is generated meanwhile (Koenig and Liu, 2001):

$$
\begin{aligned}
& 1.06 \mathrm{NO}_{3}^{-}+1.11 \mathrm{~S}+0.3 \mathrm{CO}_{2}+0.785 \mathrm{H}_{2} \mathrm{O} \\
& \quad \rightarrow 0.06 \mathrm{C}_{5} \mathrm{H}_{7} \mathrm{O}_{2} \mathrm{~N}+0.5 \mathrm{~N}_{2}+1.11 \mathrm{SO}_{4}^{2-}+1.16 \mathrm{H}^{+}
\end{aligned}
$$

Similarly, based on the basic equation of E-part (Wang and Qu, 2003):

$2 \mathrm{NO}_{3}^{-}+5 \mathrm{H}_{2}+2 \mathrm{H}^{+} \rightarrow \mathrm{N}_{2}+6 \mathrm{H}_{2} \mathrm{O}$

Assuming that the bacterial yield coefficient of E-part was the same as S-part (0.057), Eq. (2) could be express as:

$$
\begin{array}{r}
1.06 \mathrm{NO}_{3}^{-}+0.3 \mathrm{CO}_{2}+3.34 \mathrm{H}_{2}+1.06 \mathrm{H}^{+} \\
\rightarrow 0.06 \mathrm{C}_{5} \mathrm{H}_{7} \mathrm{O}_{2} \mathrm{~N}+0.5 \mathrm{~N}_{2}+3.66 \mathrm{H}_{2} \mathrm{O}
\end{array}
$$

$\mathrm{H}^{+}$produced in the S-part can be used for further hydrogen denitrification in the E-part. According to the calculation of $\mathrm{H}^{+}$balance (Eqs. (1) and (3)), when the nitrate removal ratio of E-part to S-part was $\geqslant 1.09$, the whole reactor effluent will kept neutral; otherwise the whole reactor effluent $\mathrm{pH}$ will be lower than influent as a result of redundant $\mathrm{H}^{+}$formed by $\mathrm{S}$-part that can not be completely consumed by E-part.

For anode reaction, $\mathrm{CO}_{2}$ is formed prior to $\mathrm{O}_{2}$ for their electrode potential. Thus a favorable anoxic condition is provided and dissolved $\mathrm{CO}_{2}$ is also as an IC source. Besides, $\mathrm{CO}_{2}$ can adjust $\mathrm{pH}$ as well.

\subsection{Kinetics study of the S-part}

The nitrate and nitrite concentration of effluent from S-part under different nitrogen volume-loading rates during the whole operation period is shown in Fig. 2a. It could be seen that by the decrease of HRT, nitrogen volume-loading rate became larger; the concentration of effluent nitrate increased steadily, and the same phenomena appeared as nitrites. The removal efficiency decreased from $98.3 \%$ to $66.8 \%$ when nitrogen volume-loading rate increased from 0.12 to $0.24 \mathrm{~kg} \mathrm{~N} / \mathrm{m}^{3} \mathrm{~d}$.

Kinetics of biological denitrification is usually assumed to be described by Monod expressions (Zeng and Zhang, 2005). Since
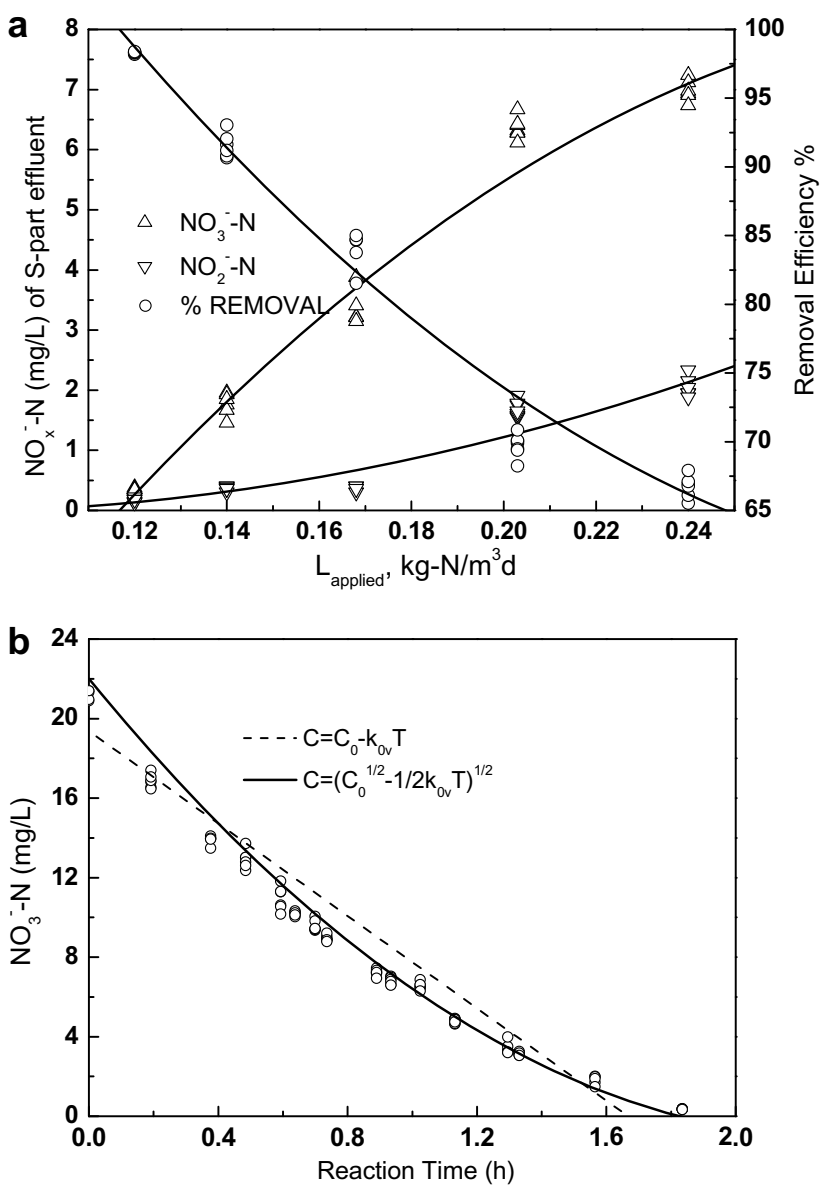

Fig. 2. (a) $\mathrm{NO}_{3}^{-}-\mathrm{N}$ and $\mathrm{NO}_{2}^{-}-\mathrm{N}$ in the effluent from $\mathrm{S}$-part as a function of nitrogen volume-loading rate and (b) two kinetics models fitted for sulfur autotrophic denitrification.

the Monod saturation constant $K_{\mathrm{s}}$ of autotrophic denitrification is very low (e.g. Batchelor and Lawrence reported a $K_{\mathrm{s}}$ value of $0.03 \mathrm{mg} / \mathrm{L}$ as $\mathrm{NO}_{3}^{-}$(Batchelor and Lawerence, 1978); Claus and Kutzner reported a $K_{\mathrm{s}}$ value of $0.2 \mathrm{mg} / \mathrm{L}$ as $\mathrm{NO}_{3}^{-}$(Claus and Kutzner, 1985)), the intrinsic kinetics of the biofilm can be taken as a zeroorder reaction. And the following two equations for substrate removal can obtained using a simplified pore diffusion model based on the assumptions of steady-state condition and substrate transport in the biofilm according to Fick's diffusion law (Harremoes, 1976; Jasen and Harremoes, 1985).

Zero-order bulk reaction: Based on the assumption that the kinetics at conditions that sulfur as substrate was sufficient and there was no mass-transfer limitation into the biofilm (Wang, 1998; Liu and Koenig, 2002; Moon et al., 2004). It can be expressed as:

$r_{v}=K_{0 v}$ valid when $\beta=\sqrt{\frac{2 D_{i} C_{i}}{K_{0 v} \delta}} \geqslant 1$

where $r_{v}$ is the removal rate per unit biofilm area $\left(\mathrm{mg} / \mathrm{dm}^{2} \mathrm{~h}\right) ; C_{i}$ is the bulk concentration of substrate at the surface of the biofilm $(\mathrm{mg} / \mathrm{L}) ; D_{i}$ is the diffusion coefficient of substrate $\left(\mathrm{dm}^{2} / \mathrm{h}\right) ; K_{o v}$ is the zero-order reaction rate constant per unit biofilm area $(\mathrm{mg} /$ $\left.\mathrm{dm}^{2} \mathrm{~h}\right) ; \beta$ is the penetration ratio, and $\delta$ is the thickness of the biofilm (dm).

Half-order bulk reaction: Based on the hypotheses that the kinetics at conditions that the nitrate concentration was not so high that it can not penetrate the whole biofilm; and development of this 
model had been applied in a number of studies (Wang, 1998; Koenig and Liu, 2001; Moon et al., 2004). It can be expressed in integrated form:

$r_{v}=K_{\frac{1}{2} v} C_{i}^{1 / 2}$ valid when $\beta<1$

where $K_{1} v$ is the half-order reaction rate constant per unit biofilm area $\left(\mathrm{mg}^{2} 1 / 2 / \mathrm{dm}^{1 / 2} \mathrm{~h}\right)$.

In this reactor, the upward flow of groundwater through the sulfur and anthracite granules medium layer for autotrophic denitrification can be considered as the flow pattern of a plug flow reactor. The effluent concentration of a plug flow reactor can be calculated by the following equation:

Zero-order bulk reaction:

$C=C_{0}-K_{0 v} T$

Half-order bulk reaction:

$C=\left(C_{0}^{1 / 2}-\frac{1}{2} K_{\frac{1}{2} v} T\right)^{2}$

where $C_{0}(\mathrm{mg}-\mathrm{N} / \mathrm{L})$ is the initial concentration of nitrate; $T(\mathrm{~h})$ is the reaction time which can be calculated by flux and relevant effective liquid volume of S-part; $C(\mathrm{mg}-\mathrm{N} / \mathrm{L})$ is the concentration of effluent nitrate at reaction time $T(\mathrm{~h})$.

In the above two kinetics models, Eqs. (6) and (7) give methods to calculate kinetics parameters and coefficients. These can be used to calculate sulfur autotrophic denitrification rate, the very important parameter to describe sulfur autotrophic denitrification of fixbed system. Fig. $2 \mathrm{~b}$ shows the nitrate concentration in the S-part as a function of reaction time, and also gives the results of experimental data fitted to the two kinetics models. Table 1 lists the calculated parameters and correlation coefficients. It can be seen from Table 1 that the experimental data is in better agreement with half-order kinetics model on the basis of correlation coefficients $\left(R^{2}\right)$.

Since the proportion of effective liquid volume of S-part volume to total effective liquid volume was 0.431 , the relationship between nitrate concentration of S-part effluent and HRT can be expressed as:

$C=\left(4.55-0.431 \cdot \text { HRT } \cdot \frac{1}{2} K_{\frac{1}{2} v}\right)^{2}$

and when $\frac{1}{2} K_{\frac{1}{2} v}=2.09\left(\mathrm{mg}^{1 / 2} / \mathrm{dm}^{1 / 2} \mathrm{~h}\right)$, that becomes:

$C=(4.55-0.90 \cdot \mathrm{HRT})^{2}$

If HRT $\geqslant 5.05 \mathrm{~h}$, nitrate could be completely decreased by Spart, and there was no need for E-part to reduce nitrate, so the maximum HRT and the minimum flux of this system were $5.05 \mathrm{~h}, 6.62 \mathrm{~L} / \mathrm{h}$, respectively. And, the minimum nitrogen volume-loading rate was $0.10 \mathrm{~kg} \mathrm{~N} / \mathrm{m}^{3} \mathrm{~d}$.

It was also indicated that the biofilm was thick enough and the nitrates diffusion in the biofilm was the limitation step in the S-part. Sulfur autotrophic denitrification rate first achieved the maximum at bottom of the S-part, and then became lower as the nitrate decreased; it lowered to the minimum value at the top of the S-part.

Table 1

Kinetics parameters and correlation coefficients $\left(R^{2}\right)$ for the two kinetic models

\begin{tabular}{llll}
\hline Kinetics model & \multicolumn{3}{l}{ Kinetics coefficients } \\
\cline { 2 - 4 } & $C_{0 \text { cal }}\left(\mathrm{NO}_{3}^{-}-\mathrm{N} \mathrm{mg} / \mathrm{L}\right)$ & $K_{0 v}$ or $\frac{1}{2} K_{\frac{1}{2} v}$ & $R^{2}$ \\
\hline$C=C_{0}-K_{0 v} T$ & 19.37 & 11.62 & 0.9500 \\
$C=\left(C_{0}^{1 / 2}-\frac{1}{2} K_{\frac{1}{2} v} T\right)^{2}$ & 20.72 & 2.09 & 0.9790 \\
\hline
\end{tabular}

\subsection{Sulfate in the effluent}

In this study, sulfate was the only product of sulfur oxidation detected in the effluent, and thiosulfate was under detection limit $(0.1 \mathrm{mg} / \mathrm{L})$ due to its low concentration. From Fig. 3a it could be founded that sulfate concentration was largely affected by nitrogen volume-loading rate. With the increase of nitrogen volume-loading rate, the removal efficiency of S-part decreased. And the sulfate concentration appeared a decreasing tendency. The sulfate concentration decreased from $243 \mathrm{mg} / \mathrm{L}$ to $200 \mathrm{mg} / \mathrm{L}$ when nitrogen volume-loading rate increased from 0.12 to $0.24 \mathrm{~kg} \mathrm{~N} / \mathrm{m}^{3} \mathrm{~d}$. It can also be seen from Fig. $3 b$ that the removed nitrate is well linearly fitted with the formed sulfate with high correlation coefficients $\left(R^{2}=0.9836\right)$. The average concentration ratio of formed sulfate concentration to removed $\mathrm{NO}_{3}^{-}-\mathrm{N}$ was 7.14 , which was very near to the stoichiometric value of 7.18. Fig. 3a also shows that the sulfate concentration of effluent during the whole operation time was lower than $250 \mathrm{mg} / \mathrm{L}$, the drinking water standard of sulfate from China EPA.

In this combined process, the sulfate concentration of the effluent was linearly fitted with removed nitrate of S-part, and it could be controlled by the nitrogen volume-loading rate. Therefore, the effluent sulfate concentration of this system would be much lower than SLAD system by increasing the nitrogen volume-loading rate.
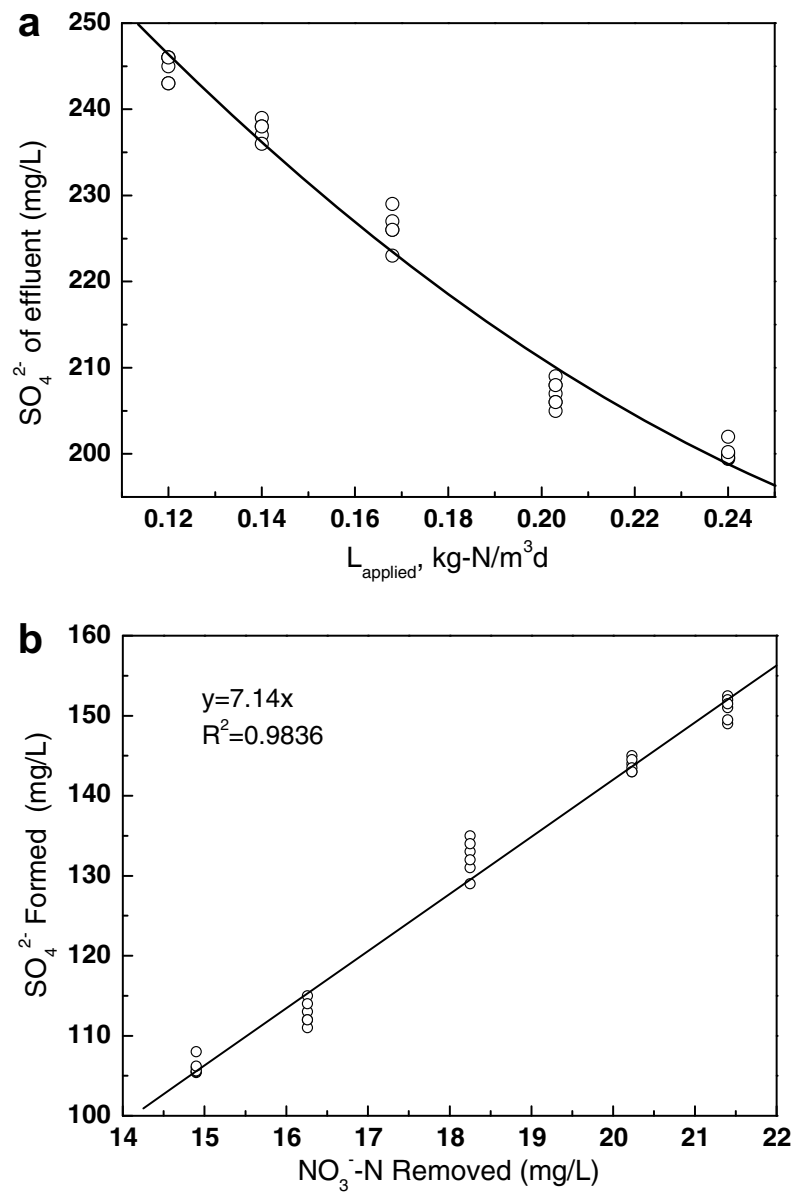

Fig. 3. (a) Sulfate concentration of effluent as a function of nitrogen volume-loading rate and (b) removed nitrate as a function of formed sulfate in the S-part. 
3.4. Optimum current applied at different nitrogen volume-loading rate

Fig. 4 shows performance of reactor under different currents and nitrogen volume-loading rates. In this reactor, nitrate was firstly denitrified in S-part, and then the residual nitrate and formed nitrite from S-part were both further reduced by hydrogen denitrfication in E-part. It could be concluded form kinetics study of the S-part that with the increase of nitrogen volume-loading
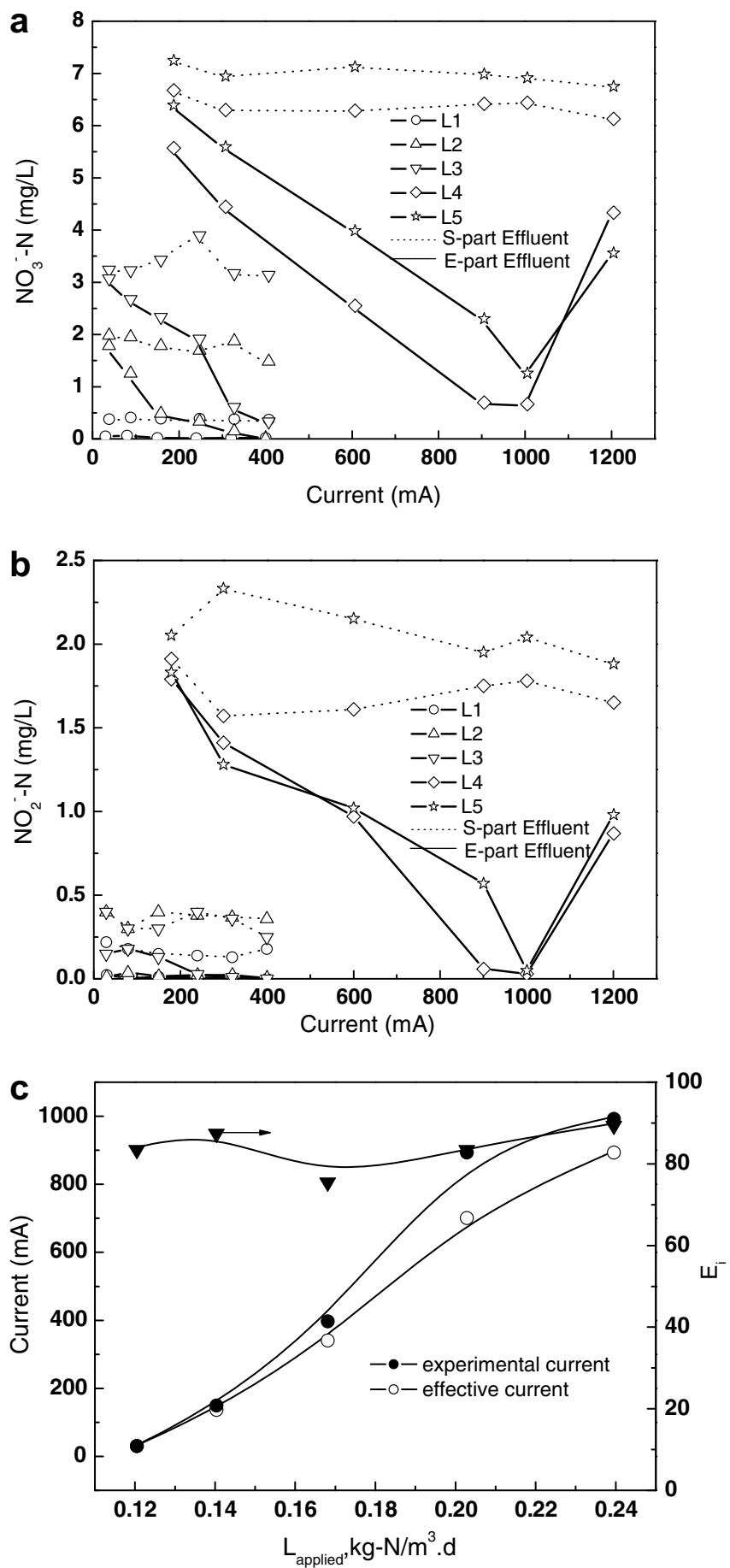

Fig. 4. ( $\mathrm{a}$ and $\mathrm{b}$ ) $\mathrm{NO}_{3}^{-}-\mathrm{N}$ and $\mathrm{NO}_{2}^{-}-\mathrm{N}$ in the effluent as a function of applied current and nitrogen volume-loading rate $\left(L_{1}=0.12 \mathrm{~kg} \mathrm{~N} / \mathrm{m}^{3} \mathrm{~d} ; \quad L_{2}=0.14 \mathrm{~kg} \mathrm{~N} / \mathrm{m}^{3} \mathrm{~d}\right.$; $L_{3}=0.17 \mathrm{~kg} \mathrm{~N} / \mathrm{m}^{3} \mathrm{~d} ; L_{4}=0.20 \mathrm{~kg} \mathrm{~N} / \mathrm{m}^{3} \mathrm{~d} ; L_{5}=0.24 \mathrm{~kg} \mathrm{~N} / \mathrm{m}^{3} \mathrm{~d}$ ) and (c) efficiency of optimum current at different nitrogen volume-loading rates. rate, the concentration of effluent nitrate increased and nitrite formed as well, so higher applied current was in need. From Fig. $4 \mathrm{a}$ and $\mathrm{b}$ it can be seen that low current $(\leqslant 400 \mathrm{~mA})$ was suitable for E-part when nitrogen volume-loading rate ranged from 0.12 to $0.17 \mathrm{~kg} \mathrm{~N} / \mathrm{m}^{3} \mathrm{~d}$. Residual nitrate and nitrite in effluent from the S-part can be well hydrogen denitrified in the E-part. The optimum currents applied at nitrogen volume-loading rates of 0.12 , $0.14,0.17 \mathrm{~kg} \mathrm{~N} / \mathrm{m}^{3} \mathrm{~d}$ were $30,150,400 \mathrm{~mA}$, respectively; and corresponding nitrate removal efficiency were up to $98 \%$ without nitrite accumulation. Furthermore, both the nitrate and nitrite removal were increased steadily with the increase of applied currents. It can also be concluded that the applied current was the key influencing factor in the CBSAD process under the voltage from 0.5$5.0 \mathrm{~V}$ with the HRT ranged from 4.2 to $2.4 \mathrm{~h}$. But when HRT was shortened from $2.4 \mathrm{~h}$ to $2.1 \mathrm{~h}$, and nitrogen volume-loading rate increased from 0.20 to $0.24 \mathrm{~kg} \mathrm{~N} / \mathrm{m}^{3} \mathrm{~d}$, higher current (1200 mA) applied did not bring out an increase in nitrate and nitrite removal, which was caused by $\mathrm{O}_{2}$ forming on anode at voltage of $5.5 \mathrm{~V}$. The corresponding DO was $8.3 \mathrm{mg} / \mathrm{L}$ at $1200 \mathrm{~mA}$, thus the activity of hydrogenotrophic denitrificans was reduced in such aerobic condition. The suitable applied current at HRT of $2.4 \mathrm{~h}$ and $2.1 \mathrm{~h}$ were $900 \mathrm{~mA}$ and $1000 \mathrm{~mA}$, respectively. The maximum volumeloading rate of the system and the maximum surface loading rate of the cathode were $0.24 \mathrm{~kg} \mathrm{NO}_{3}^{-} \mathrm{N} / \mathrm{m}^{3} \mathrm{~d}, 0.33 \mathrm{mg} \mathrm{NO}-\mathrm{N} / \mathrm{cm}^{2} \mathrm{~d}$, respectively. And, the maximum flux and the minimum HRT of this system were $15.93 \mathrm{~L} / \mathrm{h}, 2.1 \mathrm{~h}$, respectively.

The effective current $\left(I_{\mathrm{E}}\right)$ of bioelectrochemical part, which can indicate efficiency of applied current, was defined as:

$I_{\mathrm{E}}=\left[\left(C_{\mathrm{NO}_{3}^{-}, \text {in }}-C_{\mathrm{NO}_{3}^{-}, \text {eff }}\right) \cdot 5+\left(C_{\mathrm{NO}_{2}^{-} \text {, in }}-C_{\mathrm{NO}_{2}^{-}, \text {eff }}\right) \cdot 3\right] \cdot F \cdot Q$

where unit of $C$ is nitrate or nitrite concentration (mol-N/L), $F$ is Faraday constant $(26.8 \mathrm{C} / \mathrm{mol}), Q$ is the flux $(\mathrm{L} / \mathrm{h})$. The electric current efficiency and be calculated as: $E_{i}=I_{\mathrm{E}} / I$. It can be seen from Fig. $4 \mathrm{c}$ that efficiency of optimum current at different nitrogen volumeloading rates ranges from $76 \%$ to $90 \%$. It can be concluded that the majority of hydrogen generated by anode was utilized for autotrophic denitrification.

\section{5. $\mathrm{pH}$ in the effluent}

The pH decrease of S-part and E-part effluent at different nitrogen volume-loading rates is shown in Fig. 5. It could be seen that the $\mathrm{pH}$ decrease of S-part exhibited a decreasing tendency by

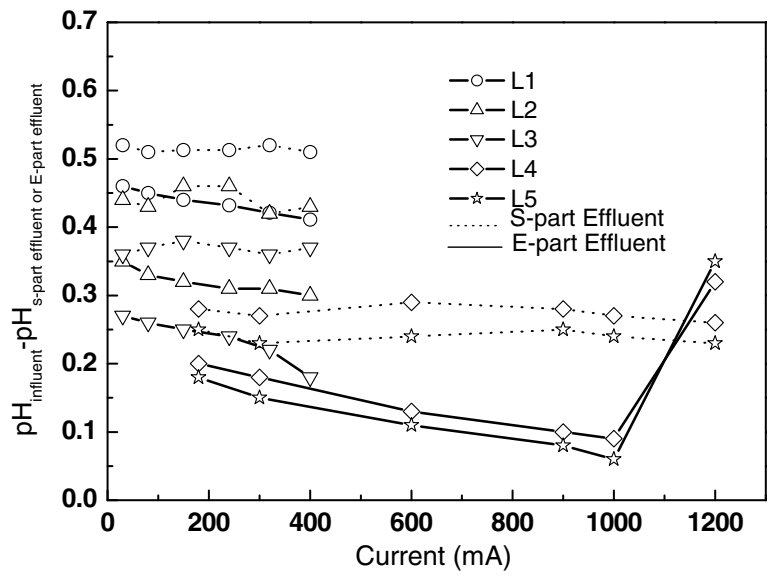

Fig. 5. pH decreases of S-part effluent and E-part effluent at different applied currents and nitrogen volume-loading rates $\left(L_{1}=0.12 \mathrm{~kg} \mathrm{~N} / \mathrm{m}^{3} \mathrm{~d} ; L_{2}=0.14 \mathrm{~kg} \mathrm{~N} /\right.$ $\mathrm{m}^{3} \mathrm{~d} ; L_{3}=0.17 \mathrm{~kg} \mathrm{~N} / \mathrm{m}^{3} \mathrm{~d} ; L_{4}=0.20 \mathrm{~kg} \mathrm{~N} / \mathrm{m}^{3} \mathrm{~d}$ and $\left.L_{5}=0.24 \mathrm{~kg} \mathrm{~N} / \mathrm{m}^{3} \mathrm{~d}\right)$. 
increasing nitrogen volume-loading rate: $\mathrm{pH}$ decreased $0.51-0.52$ for $L_{1}=0.12 \mathrm{~kg} \mathrm{~N} / \mathrm{m}^{3} \mathrm{~d}$; while $0.23-0.25$ for $L_{5}=0.24 \mathrm{~kg} \mathrm{~N} / \mathrm{m}^{3} \mathrm{~d}$.

The $\mathrm{pH}$ decrease of E-part was lower than S-part, and the $\mathrm{pH}$ decrease of E-part reduced slightly with the increase of current when the current $\leqslant 1000 \mathrm{~mA}$. The result indicated that the $\mathrm{H}^{+}$generated by S-part was consumed well by E-part. With the adjustment of Epart, neutralization could be maintained. And for the nitrate removal ratio of E-part to S-part was $<1.09$, the effluent $\mathrm{pH}$ of E-part was slightly lower than influent. It should be noticed that when higher current (1200 mA) applied, the $\mathrm{pH}$ of E-part effluent was lower than S-part. This was because alkalinity of water could be consumed by the generation of $\mathrm{O}_{2}$ at anode.

\subsection{Turbidity in the effluent}

Multiplication of biomass was very low and did not change obviously during the whole operation time. COD in the effluent of both parts was lower than $10 \mathrm{mg} / \mathrm{L}$. In this study, turbidity was used to indicate total count of bacteria of effluent from both parts. It can be seen from Fig. 6 that the turbidity of both parts was lower than 1 NTU during the whole operation time; and turbidity of E-part effluent was slightly higher than S-part effluent.

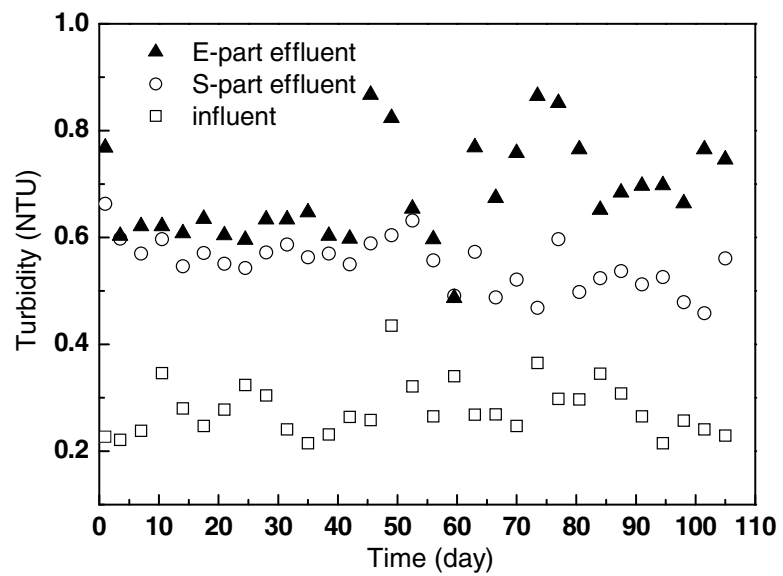

Fig. 6. Turbidity variations of influent, S-part effluent and E-part effluent at different operate stages.
In addition, cell assimilation could be estimated by VSS variation. In this study, the average VSS of effluent minus influent was $8.5 \mathrm{mg} / \mathrm{L}$. Assuming that biomass of reactor was not change obviously under the steady-state condition; $8.5 \mathrm{mg} / \mathrm{L}$ VSS increase was attributed to $\mathrm{C}_{5} \mathrm{H}_{7} \mathrm{O}_{2} \mathrm{~N}$ (final product of cell assimilation) generation; influent $\mathrm{NO}_{3}^{-}-\mathrm{N}$ was $21 \mathrm{mg} / \mathrm{L}$; and removal efficiency was $100 \%$; therefore the bacteria yield coefficient could be calculated as 0.050 , and the inaccuracy was understandable for approximate calculation.

\subsection{Comparison with other denitrification systems}

To compare with other heterotrophic biological denitrification systems (including bio-electrochemical reactors, hydrogen dependent reactor and sulfur packed-bed reactor), the main operation parameters for the best removal capacity of each reactor are summarized in Table 2:

It can be seen from Table 2 that the CBSAD system has advantages of shorter HRT, larger treatment capacity and higher removal efficiency. Compared with previous CBSAD reactor (Wang and $\mathrm{Qu}, 2003)$, the reactor was amplified for about 28 times in this study, and some regularity including kinetics study of S-part, sulfate concentration and $\mathrm{pH}$ variation as a function of nitrogen volume-loading rate was obtained this time. And it was also approved that the CBSAD system was possible for groundwater denitrification.

\section{Conclusions}

The CBSAD process was possible for groundwater denitrification. The two denitrification processes could realize and be integrated in this system.

In such process: The $\mathrm{H}^{+}$generated in the S-part could be consumed by the E-part to achieve neutralization; the effluent sulfate concentration could be controlled by the nitrogen volume-loading rate.

The denitrification rate of the S-part followed a half-order kinetics model. And the removal rate of E-part depended on the electric current.

The reactor could be operated efficiently at the nitrogen volume-loading rate ranging from 0.12 to $0.24 \mathrm{~kg} \mathrm{~N} / \mathrm{m}^{3} \mathrm{~d}$ (corresponding HRT varied from 4.2 to $2.1 \mathrm{~h}$; optimum current varied from 30 to $1000 \mathrm{~mA}$; efficiency of optimum current ranged from $76 \%$ to $90 \%$ ), and the $\mathrm{NO}_{3}^{-}-\mathrm{N}$ removal rate in the range of 95$100 \%$ without nitrite accumulation.

Table 2

Comparison with other denitrification systems

\begin{tabular}{|c|c|c|c|c|c|c|c|}
\hline Reactor & $\begin{array}{l}\text { Effective } \\
\text { volume (L) }\end{array}$ & Influent & $\begin{array}{l}\text { Initial }\left(\mathrm{NO}_{3}^{-}-\mathrm{N}\right. \\
(\mathrm{mg} / \mathrm{L})\end{array}$ & $\begin{array}{l}\text { Current } \\
(\mathrm{mA})\end{array}$ & HRT(h) & $\begin{array}{l}\text { Removal } \\
\text { efficiency }\end{array}$ & Reference \\
\hline BER $^{*}$ coupled with adsorber & 0.205 & $\begin{array}{l}\text { Synthetic } \\
\text { water }\end{array}$ & 24 & 5 & 10 & $>95 \%$ & $\begin{array}{l}\text { Feleke and Sakaibara } \\
(2002)\end{array}$ \\
\hline Multi-electrode system & 36 & $\begin{array}{l}\text { Synthetic } \\
\text { water }\end{array}$ & 20 & 960 & 6 & $80 \%$ & $\begin{array}{l}\text { Sakakibara and } \\
\text { Nakayama (2001) }\end{array}$ \\
\hline BER $^{*}$ combined with microfiltration & 0.6 & $\begin{array}{l}\text { Synthetic } \\
\text { water }\end{array}$ & 25 & 60 & 2.88 & $80 \%$ & Prosnansky et al. (2002) \\
\hline BER $^{*}$ with a two-reactor system & 0.27 & $\begin{array}{l}\text { Synthetic } \\
\text { water }\end{array}$ & 25 & 70 & 3.3 & $92 \%$ & Szekeres et al. (2001) \\
\hline $\begin{array}{l}\text { Anaerobic MBR with a novel hydrogen } \\
\text { delivery system }\end{array}$ & 5.6 & $\begin{array}{l}\text { Synthetic } \\
\text { water }\end{array}$ & 25 & - & 3 & $>98 \%$ & Rezania et al. (2007) \\
\hline Elemental sulfur packed bed reactor & - & $\begin{array}{l}\text { Synthetic } \\
\text { water }\end{array}$ & 60 & - & 4 & $96 \%$ & Koenig and Liu (2001) \\
\hline The CBSAD system of previous Study & 1.23 & $\begin{array}{l}\text { Synthetic } \\
\text { water }\end{array}$ & 30 & 16 & 1.9 & $90 \%$ & Wang and Qu (2003) \\
\hline The CBSAD system in this study & 33.47 & $\begin{array}{l}\text { Ground } \\
\text { water }\end{array}$ & $20.9-22.0$ & 1000 & 2.1 & $95 \%$ & This study \\
\hline
\end{tabular}

Bio-electrochemical reactor. 


\section{Acknowledgements}

This work was supported by the National High Technology Research and Development Program of China (Grant No. 2006AA06Z302).

\section{References}

APHA, AWWA, WEF, 1992. Standard Methods for the Examination of Water and Wastewater. APHA, Washington, DC.

Batchelor, B., Lawerence, A.W., 1978. Autotrophic denitrification using elemental sulfur. J. Water Pollut. Control Fed. 50, 1986-2001.

Chen, J.P., Chua, M.L., Zhang, B.P., 2002. Effects of competitive ions, humic acid, and $\mathrm{pH}$ on removal of ammonium and phosphorous from the synthetic industrial effluent by ion exchange resins. Waste Manage. 22, 711-719.

Claus, G., Kutzner, H.T., 1985. Physiology and kinetics of autotrophic denitrification by Thiobacillus denitrificans. Appl. Microbiol. Biotechnol. 22, 283-288.

Feleke, Z., Arakf, K., Sakakibara, Y., Watanabe, T., Kuroda, M., 1998. Selective reduction of nitrate to nitrogen gas in a biofilm-electrode reactor. Water Res. 32 (9), 2728-2734.

Feleke, Z., Sakaibara, Y., 2002. A bio-electrochemical reactor coupled with adsorber for the removal of nitrate and inhibitory pesticide. Water Res. 36, 3092-3102.

Harremoes, P., 1976. The significance of pore diffusion to filter denitrification. J. Water Pollut. Control Fed. 48, 377-388.

Jasen, J.C., Harremoes, P., 1985. Removal of soluble substrates in fixed films. Water Sci. Technol. 17, 1-14.

Kimura, K., Nakamura, M., Watanabe, Y., 2002. Nitrate removal by a combination of elemental sulfur-based denitrification and membrane filtration. Water Res. 36 (7), 1758-1766

Kleinjans, J.C., Albering, H.J., Marx, A., Van Maanen, J.M., Van Agen, B., Ten Hoor, F., Swaen, G.M. Mertens, P.L., 1991. Nitrate contamination of drinking water: evaluation of genotoxic risk in human population. Environ. Health Persp. 94, 189-193.

Koenig, A., Liu, L.H., 2001. Kinetic model of autotrophic denitrification in sulphur packed-bed reactors. Water Res. 35 (8), 1969-1978.

Liu, L.H., Koenig, A., 2002. Use of limestone for $\mathrm{pH}$ control in autotrophic denitrification: batch experiments. Process Biochem. 37 (8), 885-893.
Mansell, B.O., Schroeder, E.D., 2002. Hydrogenotrophic denitrification in a microporous membrane bioreactor. Water Res. 36 (19), 4683-4690.

Moon, H.S., Ahn, K.-H., Lee, S., Nam, K., Kim, J.Y., 2004. Use of autotrophic sulfuroxidizers to remove nitrate from bank filtrate in a permeable reactive barrier system. Environ. Pollut. 129 (3), 499-507.

Nolan, B.T., Ruddy, B.C., Hitt, K.J., Helsel, D.R., 1997. Risk of nitrate in groundwaters of the United States - a national perspective. Environ. Sci. Technol. 31 (8), 2229-2236.

Prosnansky, M., Sakakibara, Y., Kuroda, M., 2002. High-rate denitrification and SS rejection by biofilm-electrode reactor (BER) combined with microfiltration. Water Res. 36 (36), 4801-4810.

Prüsse, U., Hähnlein, M., Daum, J., Vorlop, K.-D., 2000. Improving the catalytic nitrate reduction. Catal. Today 55 (1-2), 79-90.

Rezania, B., Oleszkiewicz, J.A., Cicek, N., 2007. Hydrogen-dependent denitrification of water in an anaerobic submerged membrane bioreactor coupled with a nove hydrogen delivery system. Water Res. 41 (19), 1074-1080.

Sakakibara, Y., Kuroda, M., 1993. Electric prompting and control of denitrification. Biotechnol. Bioeng. 42, 535-537.

Sakakibara, Y., Flora, J.R.V., Suidan, M.T., Kuroda, M., 1994. Modeling of electrochemically-activated denitrifying biofilms. Water Res. 28 (5), 10771086.

Sakakibara, Y., Nakayama, T., 2001. A novel multi-electrode system for electrolytic and biological water treatments: electric charge transfer and application to denitrification. Water Res. 35 (3), 768-778.

Samatya, S., Kabay, N., Yüksel, Ü., Arda, M., Yüksel, M., 2006. Removal of nitrate from aqueous solution by nitrate selective ion exchange resins. React. Funct. Polym. 66 (11), 1206-1214.

Sierra-Alvarez, R., Beristain-Cardoso, R., Salazar, M., Gómez, J., Razo-Flores, E., Field J.A., 2007. Chemolithotrophic denitrification with elemental sulfur for groundwater treatment. Water Res. 41 (6), 1253-1262.

Szekeres, S., Kiss, I., Bejerano, T.T., Soares, M.I., 2001. Hydrogen-dependen denitrification in a two-reactor bio-electrochemical system. Water Res. 35 (3) 715-719.

Wang, H.Y., Qu, J.H., 2003. Combined bioelectrochemical and sulfur autotrophic denitrification for drinking water treatment. Water Res. 37 (15), 3767-3775.

Wang, Z.S., 1998. Application of biofilm kinetics to the sulfur/lime packed bed reactor for autotrophic denitrification of groundwater. Water Sci. Technol. 37 (9), 97-104

Zeng, H., Zhang, T.C., 2005. Evaluation of kinetic parameters of a sulfur-limestone autotrophic denitrification biofilm process. Water Res. 39 (20), 4941-4952. 